\title{
CHARACTERISTIC PATTERN OF SPECIES DIVERSITY ON THE CANARY ISLANDS
}

\author{
Manuel Jonas Steinbauer and Carl Beierkuhnlein \\ With 6 figures and 2 tables \\ Received 05. November 2009 · Accepted 18. February 2010
}

\begin{abstract}
Summary: We use an island specific presence/absence data set for the Canary Islands' Arthropoda, Spermatophyta, Fungi, Lichenes, Bryophyta, Mollusca, Chordata, Pteridophyta, Annelida and Nematoda to assess the relative influence of environmental and historical factors on species distribution and endemism. Species richness and the percentage of island endemic species as well as similarity indices for island comparisons were calculated for all species groups. Hierarchical partitioning is used to identify the independent and joined influence of 21 environmental and historical variables. The pattern of species richness is best explained by island elevation. Elevation reflects a variety of factors that contribute to habitat diversity. A similar pattern is detected for the "percentage of single island endemics" (pSIE), a factor associated with speciation. Variables associated with geographical distance have highest explanatory power for biotical similarity of islands. Various Canary Islands species groups show strong distance-decay within the archipelago. According to our findings, speciation is not necessarily driven by species richness or island age alone. Thus, we conclude that correlations between species richness and pSIE, identified in previous studies, could represent an artefact related to differing degrees of isolation between zonal altitudinal ecosystems. This would lead to an increase of speciation with altitude resulting in higher values for pSIE on high altitude islands.
\end{abstract}

Zusammenfassung: Für die Kanarischen Inseln wird auf Grundlage eines inselspezifischen Präsenz/Absenz-Datensatzes der Artengruppen Artbropoda, Spermatophyta, Fungi, Lichenes, Bryophyta, Mollusca, Chordata, Pteridophyta, Annelida und Nematoda die Bedeutung von Umwelt- und historischen Variablen für Artverbreitung und Endemismus bestimmt. Artenreichtum, Anteil an Inselendemiten sowie Ähnlichkeit in der Artzusammensetzung (im Vergleich der Inseln) werden inselspezifisch für alle genannten Artengruppen bestimmt. Der gemeinsame und unabhängige Anteil an der erklärbaren Varianz durch 21 untersuchte Umwelt- und historische Variablen werden mittels Hierarchischer Partitionierung ermittelt. Das Muster der Artenvielfalt lässt sich am besten durch die von einer Insel erreichten Höhe über NN. erklären. Diese Kenngröße reflektiert eine Vielzahl an Eigenschaften, welche die Vielfalt von Lebensräumen repräsentieren. Ein ähnliches Muster findet man für den Anteil der Inselendemiten, eine Variable die mit Artbildung assoziiert wird. Variablen, die mit geographischer Distanz im Zusammenhang stehen, weisen den höchsten Zusammenhang mit der biotischen Ähnlichkeit innerhalb des Archipels auf. Eine direkte Abnahme der Ähnlichkeit in der Artzusammensetzung einzelner Inseln mit deren Entfernung (,distance-decay“) findet sich für mehrere Artengruppen. Unsere Ergebnisse weisen darauf hin, dass Artbildung nicht notwendigerweise alleine von Artenreichtum oder Inselalter abhängig ist. Ein in anderen Studien gefundener Zusammenhang zwischen Artenreichtum und dem Anteil an Inselendemiten kann auch als Artefakt interpretiert werden, welches dadurch entstehen könnte, dass höhenzonale Ökosysteme einzelner Inseln unterschiedlich stark isoliert sind. Als Folge würde es zu einem Anstieg des Anteils an Inselendemiten mit der Höhe kommen. Dies zieht dann für Inseln, die eine größere Höhe erreichen, auch höhere Prozentwerte an Inselendemiten nach sich.

Keywords: Species turn-over, species-area, beta-diversity, alpha-diversity, Macaronesia, distance decay, Atlantic Ocean, island biogeography, speciation

\section{Introduction}

Ecological and evolutionary processes operate in overlapping spatial and temporal dimensions (CArroll et al. 2007; Fussmann et al. 2007; Kinnison; Hairston 2007). Heaney (2000) demonstrates that migration, extinction, and phylogenesis can be effective within comparable time spans. Therefore, it is difficult to differentiate the most influential processes responsible for the present pattern of species dis- tribution. Simplified assumptions in popular biogeographical concepts, like the idea of equilibrium, have been proven to be wrong (see Brown and Lomolino 2000; Whittaker 2000; Heaney 2007; Whittaker and Fernández-Palacios 2007). In contrast to the suggestions made by MACARTHUR and WILSON (1967), immigration and extinction are not necessarily continuous processes, but can occur in the context of discrete events ("taxon pulses") (RiCKLEFS and Bermingham 2002; Halas et al. 2005). 
The identification of variables that control processes and patterns in ecological systems is of major concern (HEANey 2007; WhitTAKer et al. 2007). The understanding of ecological processes in isolated regions, such as fragmented landscapes or patchy ecosystems, can profit from the research on island ecosystems (DuARTE et al. 2008). By studying drivers for floristic richness on island ecosystems, various authors contributed to an improved understanding of global patterns of biodiversity (e.g. Morrison 2002; Willerslev et al. 2002; Price 2004; Roos et al. 2004; McMaster 2005; Panitsa et al. 2006; Dapporto and Dennis 2008; Duarte et al. 2008; Hannus and von Numers 2008).

The mere area of potential habitats is an important, albeit indirect, physical parameter that can be used to analyse patterns of species distribution (McMaster 2005; Whittaker and FernándezPalacios 2007). For many archipelagos, a certain correlation of area with species number is documented (e.g. Price 2004; Roos et al. 2004; McMaster 2005; Duarte et al. 2008; Hannus and vON Numers 2008). This linkage was even said to be one of the most powerful "rules" in ecology (Lomolino 2000b; Tjorve 2003; Triantis et al. 2003). Nevertheless, the functional background of this pattern is manifold and can hardly be traced precisely due to ecological complexity. Various explanations are under debate. The "habitat diversity hypothesis" (Williams 1964) assumes that a larger area, due to its supposed spatial heterogeneity, is connected with the conditional probability of hosting more species. According to the "area per se" hypothesis (Preston 1960; MacArthur and Wilson 1967) larger areas host more species, as the extinction risk of local populations is reduced on larger surfaces. Furthermore, according to the "passive sampling hypothesis" (CONNOR and MCCOY 1979) and the "target area hypotheses" (MACARTHur and WiLson 1967), the chance of an area to be colonised by locally "new" species increases with its size. The relevance of proximity is highlighted by the "rescue hypothesis" (BRown and KODRICBrown 1977). It predicts declining populations or species that do not surpass minimum viable population sizes to be maintained when large and viable populations are close by and individuals or diaspores can disperse. This dynamic directly refers to the "source sink theory" for metapopulations introduced by Pulliam (1988). According to this concept, (large or suitable) habitat patches with population growth beyond their capacity contribute to the maintenance of habitat patches that can not sustain permanent viable populations. For general overviews see Triantis et al. (2003), Roos et al. (2004), Beierkuhnlein (2007) and Whittaker and FERnÁndeZ-Palacios (2007).

Investigating a spectrum of physical and historical factors may reveal the processes behind single explanatory variables such as area. Such an approach has to be designed in a manner that allows assessing whether species richness, despite being correlated with area ("area per se" hypothesis), could be explained by parameters associated with habitat diversity ("habitat diversity hypothesis"). The "passive sampling -", the "target area -", the "rescue hypothesis" and the "source-sink theory" are more associated to an island's isolation from the target species source region. In this case, spatial filters like distance might be more important by reducing the probability of migratory and dispersal success.

Hannus and von Numers (2008) find both island area and habitat diversity to be correlated with species richness for an island archipelago in south-western Finland. For Mediterranean islands, Sснмітт (1998) identified a linear increase in the number of taxa in ferns and flowering plants with elevation and log (area). Including endemic species can provide information on speciation processes. For the west Italian islands, DAPPORTO and Dennis (2008) confirm the influence of distance to the nearest landmass source on species assemblage, species richness and endemism.

In this study, we test whether the number of species on an island and the dissimilarity in the species pool of islands are predominantly determined by ecological or spatial factors. The ecological background and the availability and heterogeneity of habitats directly control resource availability and ecological niches. It can be assumed that this is more important for species diversity than mere spatial or temporal qualities, which are considered in traditional island biogeography (BEIERKUHNLEIN 1998). Habitat conditions are characterized in our study by a set of variables such as soil traits, geology, precipitation, temperature, forest cover, human population, inclination and elevation ("ecological setting"). A second group of variables was selected with focus on geographical aspects related to an island's isolation (distance to Africa, distance to next island, human induced connectivity, mean distance to the islands in the archipelago). These variables are revered as "spatial setting". As discussed above, area (active surface) could be associated with both categories. In addition, the historic factors "time" (available for 
evolution and immigration) and "age" of the island (existence) are analysed and discussed. These two terms are not necessarily exchangeable.

We hypothesize that species number is predominantly controlled by ecological settings and not by spatial settings (H1). Therefore, physical factors representing habitat diversity should explain more of the variance of the species richness patterns than isolating spatial parameters. Comparable analyses were applied for other archipelagos (e.g. MORRISON 2002; Willerslev et al. 2002; Price 2004; Roos et al. 2004; McMaster 2005; Panitsa et al. 2006; Dapporto and Dennis 2008; Duarte et al. 2008; Hannus and von Numers 2008). Besides methods applied in these studies, similarity indices for beta diversity are calculated for the Canarian flora and fauna. We test if similarity in species compositions ("differentiation diversity" sensu JURASINSKI et al. 2009) between the islands of the Canary Archipelago is more influenced by environmental isolation (species from a source region do not find suitable habitats) and less by spatial isolation (these species can not reach suitable habitats on the island) (H2). This is the first time, the relationship between distance in environmental parameters and similarity of species composition has been investigated on oceanic islands.
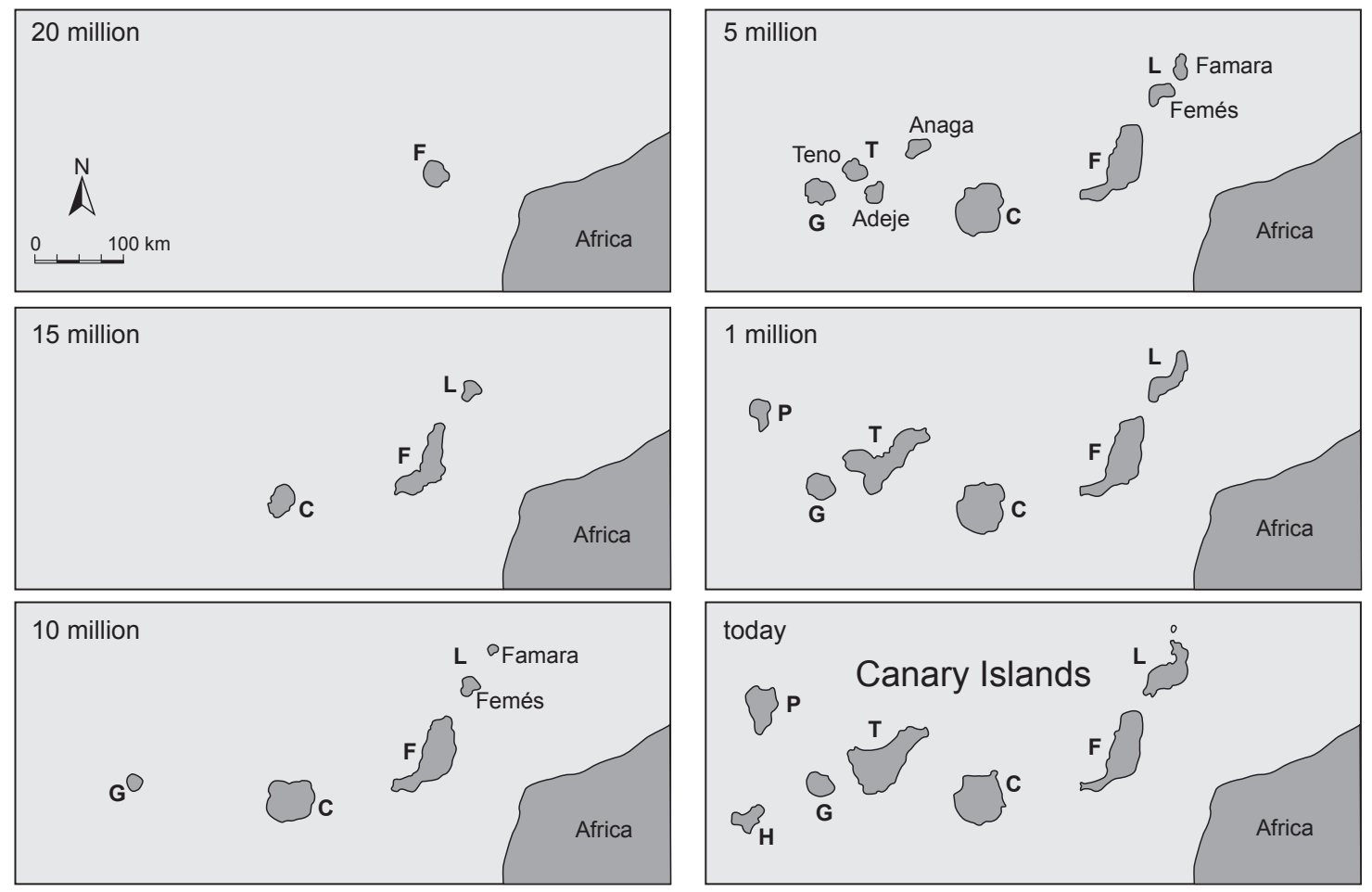

Fig. 1: History of the volcanic evolution of the Canarian Archipelago: $\mathrm{L}=$ Lanzarote, $\mathrm{F}=$ Fuerteventura, $\mathrm{C}=\mathrm{Gran} \mathrm{Canaria}$, T=Tenerife, $\mathrm{P}=\mathrm{La}$ Palma, $\mathrm{G}=\mathrm{La}$ Gomera, $\mathrm{H}=\mathrm{E} 1$ Hierro (Modified after MArrero and Francisco-OrTEga 2002). 
The islands have always been separated from the African mainland by a trench which has a recent depth of at least $1,500 \mathrm{~m}$. Sea level changes driven by glacial/interglacial cycles of the Pleistocene were responded by a fluctuating distance to Africa ranging from $60 \mathrm{~km}$ (glacial period with low sea-level) to $95 \mathrm{~km}$ today (García-Talavera 1999; FernándeZPalacios and WhitTaker 2008).

The seven main islands differ noticeable in size, altitude, and age. Tenerife is seven times larger than El Hierro and its highest elevation, El Teide (3,718 $\mathrm{m})$, is by far higher than for instance on Lanzarote $(670 \mathrm{~m})$. These topographic differences are reflected by climatic gradients within and between islands. On Tenerife, mean annual temperature at the highest meteorological station (Cañadas-Pico Teide; 3,530m asl) is $3.5^{\circ} \mathrm{C}$, while the lowest station (Anaga-San Andrés; $20 \mathrm{~m}$ asl), records $20.6^{\circ} \mathrm{C}$ mean annual temperature (Del Arco et al. 2006). Because of the predominant north-eastern trade winds, precipitation varies especially between north-eastern and southwest facing slopes. On Tenerife, the station with the lowest annual precipitation (Guía de Isora-Alcalà Chiquita; $70 \mathrm{~m}$ asl) is located on the south-western coast in the rain shadow of El Teide. It only has $47.4 \mathrm{~mm}$ of annual precipitation. Highest precipitation is recorded on the Esperanza Ridge (MatanzaLagunetas; $1,400 \mathrm{~m}$ asl) on the north-eastern part of the island with $928 \mathrm{~mm}$ of annual precipitation (DEL ArCo et al. 2006). Despite the indicated spatial variations and regional climate distinctions, in general the Canary Islands are characterised by an even-tempered, subtropical climate that is balanced by the sea, constant trade winds and ocean currents.

\section{Methods}

This study analyses presence/absence data for Arthropoda (7,044 species), Spermatophyta (1,962 species), Fungi (1,713 species), Lichenes (1,262 species), Bryophyta (474 species), terrestrial Mollusca (240 species), Chordata (137 species), Pteridophyta (63 species), Annelida (61 species) and Nematoda (31 species) for the seven Canarian main islands. The data were obtained from IZQuiERDo et al. (2004). Subspecies were excluded. Altogether the dataset contains 12,997 species of which 3,663 are endemic to the Canary Islands.

In a first survey, species richness and the percentage of island endemic species (pSIE) for the different species groups were analysed. Variables used to describe island characteristics are listed in table 1 and 2 .
To identify the amount of total variation explained by ecological, spatial and historic variables, a hierarchical partitioning was conducted. Hierarchical partitioning was developed to estimate the joint and independent contribution of correlated predictor variables. The independent contribution is the part of variance that only one single predictor can explain, while the joint contribution can be explained by more than one predictor. Hierarchical partitioning computes the independent contribution by comparing the goodness-of-fit of all possible models with and without a predictor variable (for more details see CHEVAN and SUTHERLAND 1991; MAC NALLY 2002). The purpose of hierarchical partitioning is not to calculate a predictive model, but to generate a detailed basis for inferring causality in multivariate regression settings (WATSON and Peterson 1999). HeikKinen et al. (2005) suggest hierarchical partitioning, as it contributes to a better understanding of predictive variables in ecological studies.

Hierarchical partitioning was conducted using linear regression and $\mathrm{R}^{2}$ as the goodness-of-fit measure implemented in the package "hier.part" version 1.0-3 (WALSH and MAC NALlY 2008) within the statistical program R (R DEVELOPMENT CORE TEAM 2008).

As the algorithm is only capable to consider nine variables, the variables with highest explained variance were identified in a preliminary investigation. Hierarchical partitioning was applied on nine coincidentally chosen variables. Then, these variables were weighted according to their explained variance. This procedure was repeated 500 times. Weighting scores for each variable were summed up and those nine variables with the highest cumulative scores were chosen for the final hierarchical partitioning.

As hierarchical partitioning does not provide significance values, a separate linear regression model was calculated for each predictor with the dependent variable (linear regression and $\mathrm{R}^{2}$ as the goodness-of-fit measure). Significance $(\mathrm{p}<0.05)$ was tested using F-test as implemented in function " $\mathrm{m}$ " within the statistical program $\mathrm{R}$.

In a further analysis, the explanatory power for the similarity in species composition was assessed. For the survey of similarity between the Canary Islands, the Simpson Index was chosen. This index is independent of richness (KolEFF et al. 2003; BASELGA 2007) and is widely used. Similarity indices were calculated by using R-package "simba" version 0.2-5 (JuRASINSKI 2007).

The geographical distance between the islands and the calculated Euclidean distance of selected 
Table 1: References and descriptions for the variables used for the analyses. "Island circumference" as well as "inclination under 20\%" (not listed here) were not included in later calculations, as they are strongly correlated with "area $2 \mathrm{D}$ " and "inclination", respectively.

\begin{tabular}{|c|c|c|}
\hline Variable name & Description & Reference \\
\hline Area 2D & Island area in a two dimensional projection & INSTITUTO NACIONAL DE ESTADISTICA (2005) \\
\hline Area 3D & $\begin{array}{l}\text { Three dimensional island area calculated from a digital } \\
\text { elevation model. }\end{array}$ & SRTM-data performed in ENVI 4.0 \\
\hline Elevation & Island elevation & INSTITUTO NACIONAL DE ESTADISTICA (2005) \\
\hline Time & $\begin{array}{l}\text { Represents the time that was available for species } \\
\text { immigration and evolution on an island. As suggested by } \\
\text { Whittaker et al. (2007, 2008), an age of } 8 \text { million years was } \\
\text { chosen for Tenerife, as at that time the lava domes that } \\
\text { would later form the island exceeded see level. Due to the } \\
\text { sterilising volcanic eruption } 3.5 \text { million years ago, this time } \\
\text { span was chosen for Gran Canaria. }\end{array}$ & WhiTtAKER et al. $(2007,2008)$ \\
\hline Island age & The maximum age of the island. & $\begin{array}{l}\text { In DeL Arco et al. (1996) modified with new } \\
\text { records reported in WhitTAKER et al. (2007, } \\
\text { 2008). }\end{array}$ \\
\hline Population & Human population on the island. & INSTITUTO NACIONAL DE ESTADISTICA (2005) \\
\hline Distance to Africa & The nearest geographical distance to mainland Africa. & Google Earth \\
\hline Next island & $\begin{array}{l}\text { The shortest distance to the next island measured from } \\
\text { coast to coast. }\end{array}$ & Google Earth \\
\hline Mean distance & $\begin{array}{l}\text { The mean of an island's distance to all other islands. } \\
\text { This mean island distance is the higher the closer to } \\
\text { the edge of the archipelago an island is situated }\end{array}$ & Google Earth \\
\hline Connectivity & $\begin{array}{l}\text { A measurement for travelling possibilities between the } \\
\text { islands. It represents the maximum number of ferry and } \\
\text { aerial connections that could be found per day and island. }\end{array}$ & $\begin{array}{l}\text { All available net sources that could be found } \\
\text { within a two-hour survey. }\end{array}$ \\
\hline Soil & The number of illustrated main classes in the map. & INSTITUTO GEOGRÁFICO NACIONAL (1994) \\
\hline Geology & $\begin{array}{l}\text { The number of illustrated main classes on the } \\
\text { geological map. }\end{array}$ & $\begin{array}{l}\text { Geological map assessed from GRAFCAN - } \\
\text { Sistema de información territorial, Gobierno de } \\
\text { Canarias }\end{array}$ \\
\hline Mean precipitation & Mean precipitation on the island. & FERnANDO-PulLÉ (1976) \\
\hline Max. precipitation & $\begin{array}{l}\text { Precipitation of the meteorological station with } \\
\text { highest mean precipitation on the island. }\end{array}$ & 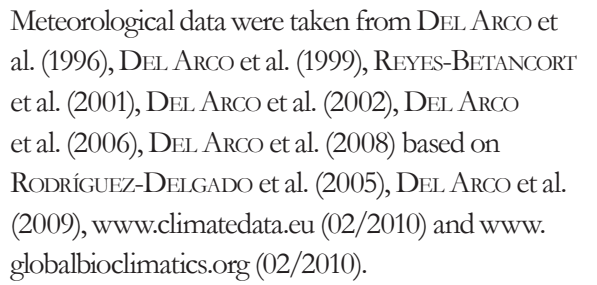 \\
\hline Min. precipitation & $\begin{array}{l}\text { Precipitation of the meteorological station with lowest } \\
\text { mean precipitation on the island. }\end{array}$ & See "max. precipitation" \\
\hline Precipitation range & The range between maximal and minimal precipitation & See "max. precipitation" \\
\hline Max. temperature & $\begin{array}{l}\text { Temperature of the meteorological station with highest } \\
\text { mean temperature on the island. }\end{array}$ & See "max. precipitation" \\
\hline Min. temperature & $\begin{array}{l}\text { Temperature of the meteorological station with lowest } \\
\text { mean temperature on the island. }\end{array}$ & See "max. precipitation" \\
\hline Temperature range & The range between maximal and minimal temperature. & See "max. precipitation" \\
\hline Forest cover & The percentage of island area that is covered by forest & $\begin{array}{l}\text { Forest management plan published by the Canarian } \\
\text { ministry (Consejería de Política Territorial y Medio } \\
\text { Ambiente Gobierno de Canarias, 2000) }\end{array}$ \\
\hline inclination & $\begin{array}{l}\text { Mean inclination of the island calculated from a digital } \\
\text { elevation model. }\end{array}$ & SRTM-data performed in ENVI 4.0 \\
\hline
\end{tabular}


Table 2: Variables used for the analyses.

\begin{tabular}{|c|c|c|c|c|c|c|c|}
\hline Variable name & $\begin{array}{c}\text { E1 } \\
\text { Hierro }\end{array}$ & $\begin{array}{c}\text { La } \\
\text { Palma }\end{array}$ & $\begin{array}{c}\text { La } \\
\text { Gomera }\end{array}$ & Tenerife & $\begin{array}{c}\text { Gran } \\
\text { Canaria }\end{array}$ & $\begin{array}{l}\text { Fuerteven- } \\
\text { tura }\end{array}$ & Lanzarote \\
\hline Area 2D $\left[\mathrm{km}^{2}\right]$ & 269 & 708 & 370 & 2034 & 1560 & 1660 & 846 \\
\hline Area 3D $\left[\mathrm{km}^{2}\right]$ & 308 & 777 & 413 & 2127 & 1645 & 1675 & 823 \\
\hline Elevation [m a.s.l.] & 1501 & 2423 & 1487 & 3718 & 1949 & 807 & 671 \\
\hline Time [million year] & 1.1 & 1.5 & 12.0 & 8.0 & 3.5 & 16.0 & 20.0 \\
\hline Island age [million year] & 1.1 & 1.6 & 12.0 & 8.0 & 13.9 & 16.1 & 20.0 \\
\hline Population [thousand] & 11 & 86 & 22 & 853 & 807 & 90 & 127 \\
\hline Distance to Africa $[\mathrm{km}]$ & 382 & 416 & 333 & 287 & 196 & 96 & 127 \\
\hline Next island [km] & 61 & 58 & 27 & 27 & 61 & 11 & 11 \\
\hline Mean distance $[\mathrm{km}]$ & 197 & 184 & 141 & 112 & 140 & 195 & 252 \\
\hline $\begin{array}{l}\text { Connectivity [number of } \\
\text { connections] }\end{array}$ & 13 & 29 & 9 & 76 & 71 & 42 & 34 \\
\hline Soil [number of main types] & 3 & 7 & 4 & 7 & 5 & 2 & 3 \\
\hline Geology [number of main types] & 9 & 10 & 11 & 27 & 21 & 22 & 11 \\
\hline Mean precipitation $[\mathrm{mm}]$ & 426 & 586 & 410 & 420 & 325 & 147 & 135 \\
\hline Precipitation range $[\mathrm{mm}]$ & 718 & 1123 & 609 & 881 & 842 & 141 & 122 \\
\hline max. precipitation [mm] & 827 & 1295 & 758 & 928 & 987 & 246 & 218 \\
\hline min. precipitation [mm] & 109 & 172 & 149 & 47 & 145 & 105 & 96 \\
\hline Temperature range $\left[{ }^{\circ} \mathrm{C}\right]$ & 9.5 & 11.7 & 8.2 & 18.6 & 8.9 & 2.5 & 3 \\
\hline max. temperature $\left[{ }^{\circ} \mathrm{C}\right]$ & 22.2 & 21.3 & 20.8 & 22.1 & 21.5 & 20.4 & 21 \\
\hline min. temperature $\left[{ }^{\circ} \mathrm{C}\right]$ & 12.7 & 9.6 & 12.6 & 3.5 & 12.6 & 17.9 & 18 \\
\hline Forest cover $[\%]$ & 24 & 45 & 25 & 24 & 10 & 0 & 0 \\
\hline Inclination $[\%]$ & 27 & 33 & 39 & 23 & 28 & 13 & 10 \\
\hline Species richness [-] & 2879 & 5189 & 4509 & 9008 & 5987 & 2839 & 2590 \\
\hline Number of Arthropoda [-] & 1310 & 2655 & 2181 & 4777 & 3151 & 1620 & 1338 \\
\hline Number of Spermatophyta [-] & 619 & 836 & 848 & 1383 & 1256 & 701 & 673 \\
\hline Number of Fungi [-] & 206 & 917 & 502 & 1073 & 477 & 31 & 60 \\
\hline Number of Lichenes [-] & 287 & 529 & 531 & 878 & 302 & 76 & 165 \\
\hline Number of Bryophyta [-] & 189 & 318 & 278 & 408 & 293 & 122 & 109 \\
\hline Number of Mollusca [-] & 33 & 55 & 62 & 103 & 69 & 30 & 35 \\
\hline Number of Chordata [-] & 63 & 65 & 68 & 104 & 95 & 68 & 62 \\
\hline Number of Pteridophyta [-] & 33 & 41 & 41 & 53 & 47 & 16 & 14 \\
\hline Number of Annelida [-] & 11 & 20 & 21 & 57 & 24 & 6 & 3 \\
\hline Number of Nematoda [-] & 8 & 9 & 9 & 24 & 9 & 3 & 8 \\
\hline Endemic species [-] & 757 & 1128 & 1181 & 2228 & 1509 & 623 & 561 \\
\hline pSIE [\%] & 5 & 5 & 7 & 10 & 9 & 5 & 4 \\
\hline
\end{tabular}

variables (listed in table 1) were implemented as predictive variables for the biogeographical analysis. As explained above, the detection of explanatory power was performed by using hierarchical partitioning.
Significance tests for linear relations between distance matrices have to account for the problem of pseudoreplication. One solution is to apply permutation tests. Here, a Mantel-test was performed 
using R-package “ecodist” version 1.1.4 (GosLEE and URBAN 2007).

Finally, the percentage of single island endemics (pSIE) was investigated in detail. The connection to species diversity and other already mentioned variables were analysed. Analyses were restricted to Arthropoda (SIE n=1,534), Spermatophyta (SIE n=294), Fungi (SIE n=99) and Mollusca (SIE $\mathrm{n}=173)$. Lichenes (SIE $\mathrm{n}=14)$, Bryophyta (SIE $\mathrm{n}=4$ ), Chordata (SIE n=6), Pteridophyta (SIE n=1), Annelida (SIE $\mathrm{n}=0$ ) and Nematoda (SIE $\mathrm{n}=1$ ) were not taken into considerations due to the small number of SIE.

\section{Results}

Altitude was attributed with the highest explanatory power for species richness (Fig. 2). It explains the largest proportion of variance for most species groups ( $\mathrm{R}^{2}$ between 0.55 and 0.90 ). Other variables such as the temperature range, the minimum temperature, precipitation range, the human population, the mean distance to the other islands, human connectivity and the number of soil types also have a high explanatory power. Due to the high inter-correlations among these variables, a precise differentiation between them seemed neither possible nor reasonable.

Good predictor variables for pSIE are human population size, mean distance to the other islands, minimum temperature and elevation (Fig. 3).

Similarity in species composition is best reflected by geographical distance, difference in the precipitation parameters and distance to mainland Africa (Fig. 4). Furthermore, the differences in inclination were a good predictor for similarity.

Median values for similarity in species composition vary between 0.9 (for Annelida) and 0.4 (Mollusca) (Fig. 5). Incomplete records in species groups that are difficult to detect or to determine, such as Fungi and Lichenes, could be the reason for low values and a high variance of similarity. Different taxa might erroneously be assumed to be identical. Some species are distinct but can not be discriminated visually. Morphological variability may lead to the description of separate species, which are in fact just varieties. Such problems are likely to occur also in Annelida and Nematoda. However, the high values of variance are probably related rather to the low number of species in these groups. The species group "Arthropoda" is rich in species and ecologically very heterogeneous. Hence, similarity values are close to the overall mean. For Chordata, the high similarity of species composition between the islands reflects the large percentage of birds with high migratory ability.Strong distance decay was identified for most species groups (Fig. 6). The explanatory power of the distance-decay relation is best for Chordata.

\section{Discussion}

\subsection{Variables correlated with the species rich- ness pattern ( $\mathrm{H} 1)$ :}

Island elevation was identified to be most suitable for describing species richness patterns on the Canary Islands (Fig. 2). This is consistent with the findings of Fernández-Palacios and Andersson (2000). Elevation summarises a variety of habitat characteristics. Together with predominant wind patterns, elevation is responsible for a manifold mesoclimate. Especially, higher elevations cause pronounced windward and leeward effects. FERNÁNDEZPalacios and Andersson (2000) find elevation to be strongly correlated $(95 \%)$ with habitat diversity on Macaronesian Islands. For the Canary Islands, elevation might substitute area as the variable summarising ecological conditions and carrying capacity. This is consistent with other oceanic island archipelagos (e.g. Намilton et al. 1963), especially if they are of volcanic origin (like Hawaii; PrICE 2004). However, a high explanatory power of elevation for area or species richness is not a global phenomenon (KREFT et al. 2008).

An increase of island species diversity with island elevation must not necessarily be caused by habitat diversity. Schoener et al. (2001) show elevation to be a key variable for species survival during catastrophic events (e.g. storm floods, fire). In addition to advantages during short-term events, elevation gradients also facilitate populations persistence and survival during long-term environmental fluctuations such as cold stages.

Besides altitude, variables like "precipitation range", "minimum temperature", "medium distance to other islands" and "number of soil types" are suitable variables to describe the distribution pattern. These variables can be understood as the integral of abiotic conditions on the islands. Elevation represents topography. "Number of soil types", "minimum temperature" and "precipitation range" are defining living conditions for biota. These variables could also be seen to repre- 

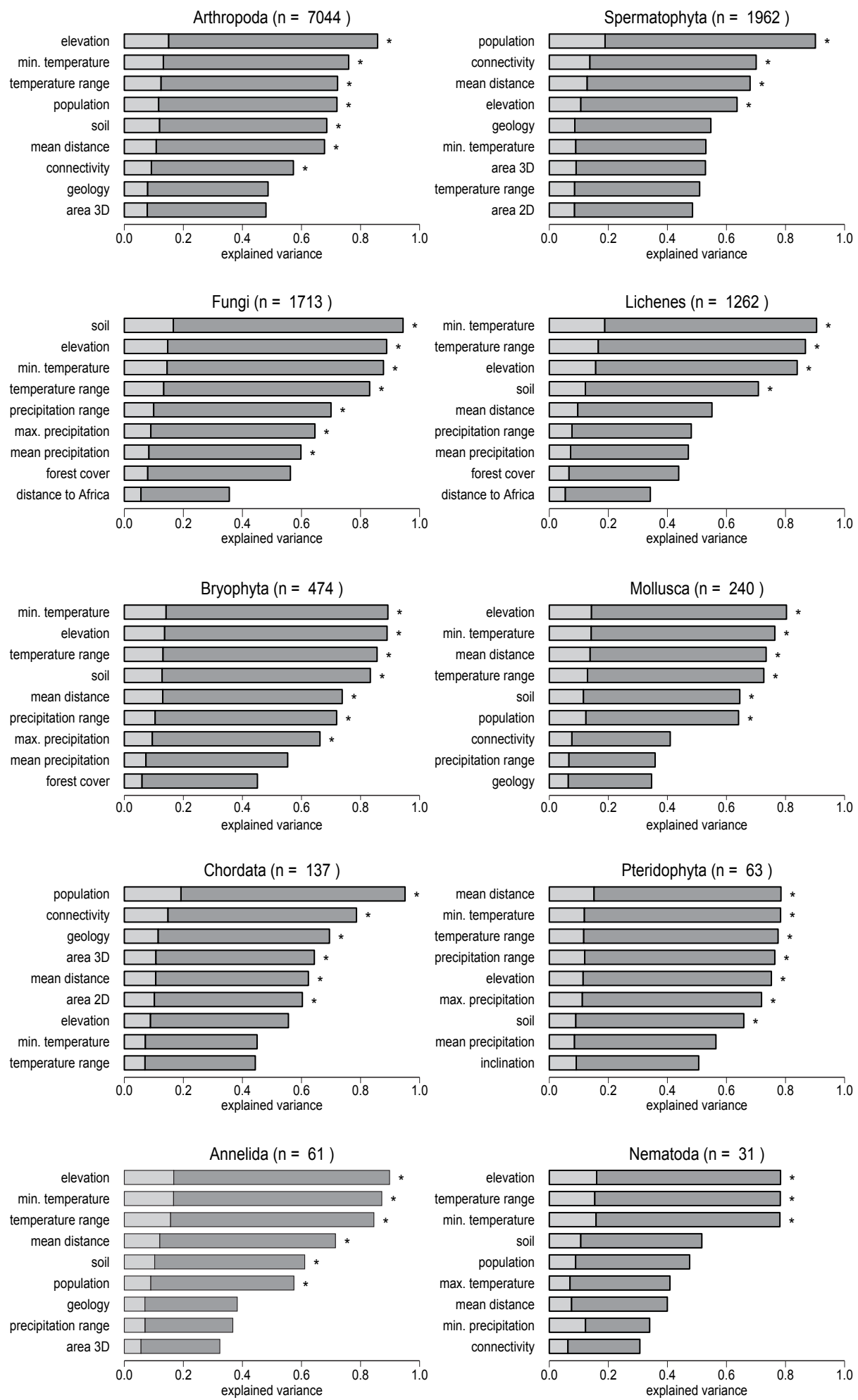

Figure 2: The number of species was analysed using hierarchical partitioning. The grey parts of the bars illustrate the amount of variance that a variable can explain independently, black parts show the amount of variance that a variable can explain together with other variables. Significance $(p<0.05)$ is indicated by a star behind the bar. 

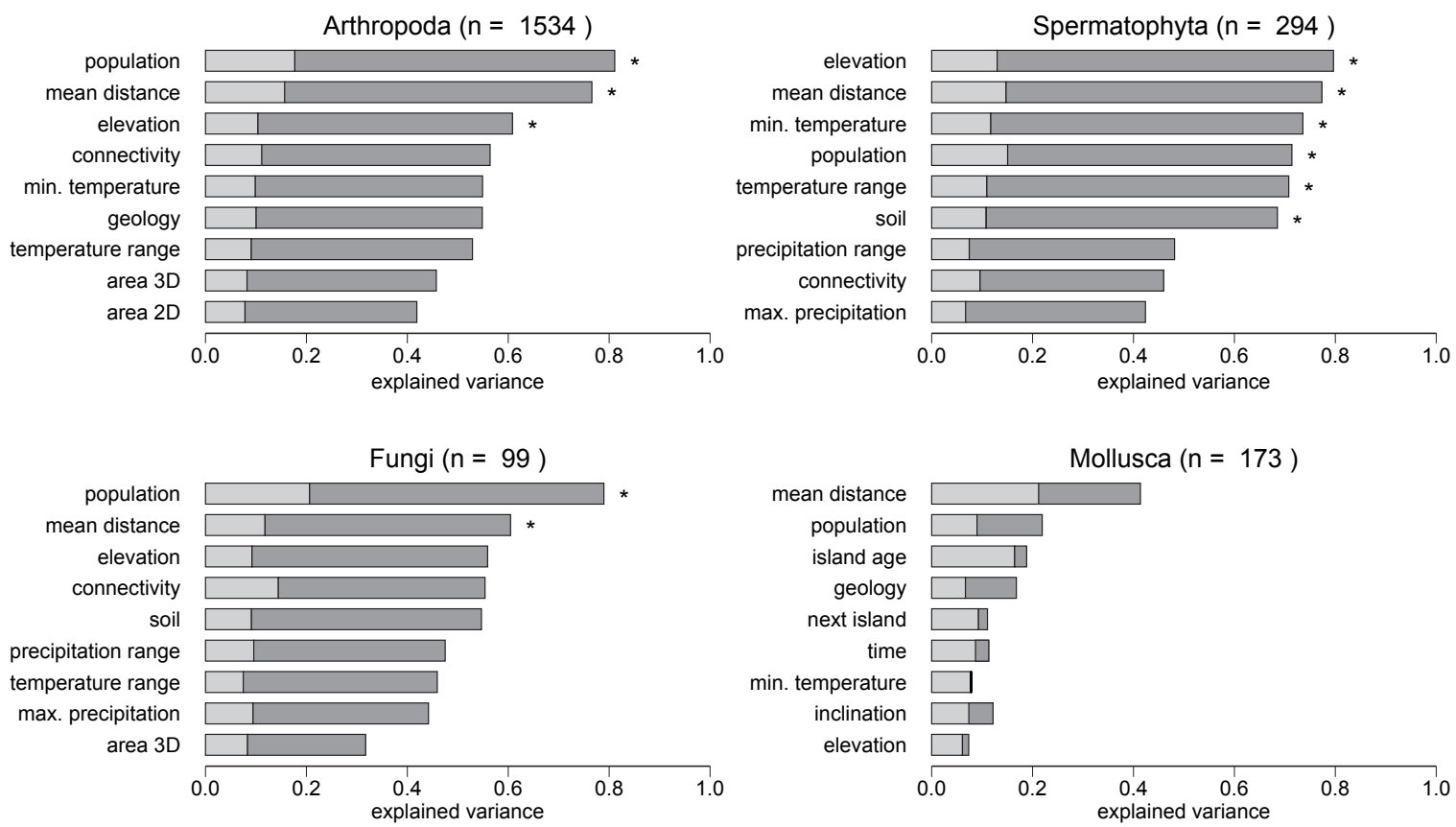

Fig. 3: The percentage of single island endemic species was analysed using hierarchical partitioning. The grey parts of the bars illustrate the amount of variance that a variable can explain independently, black parts show the amount of variance that a variable can explain together with other variables. Significance $(p<0.05)$ is indicated by a star behind the bar.

sent mechanisms that define the islands' ecological niches and carrying capacity. Consequently, even a higher rate of species immigration will not necessarily result in a much larger number of overall species. Hypothesis 1 could be proved: it is not primarily the recent distance to mainland Africa that influences species abundance on the Canary Islands. Yet the influence of distance cannot be neglected, as indicated by the effects of "mean [island] distance". The identified effect illustrates that islands located in the centre of the archipelago host more species than those at the borders. As two islands with comparably high elevations are located in the centre of the archipelago (Gran Canaria, Tenerife), one could dismiss this effect as a coincidental correlation. However, the pattern we found could also be interpreted as an indication for the importance of species exchange among the islands. This would mean that within archipelagos, immigration from neighbouring islands is more important for species richness than immigration from the mainland. This argumentation would support the results of SANMARTín et al. (2008) who applied a Bayesian modelling approach on the Canary Islands and found the inter-island dispersal within the archipelago to be more important for the explanation of diversification within lineages than dispersal between the continent and the islands.

\section{2 pSIE as an indicator for speciation:}

pSIE was introduced as a indicator for speciation on island archipelagos by EMERSON and Kolm 2005 (see also WhitTAKer et al. 2007). As pSIE and species number show colinearity for the Canary Islands, it is not surprising that again variables correlated with elevation have the highest explanatory power. However, while elevation is among the best variables that explain pSIE, it is not the overall best (compare figure 3). EMERSON and Kolm (2005) identified a correlation between species richness and PSIE for the Canary Islands. They suggested that species richness promotes speciation. In that study, species richness was, besides elevation and area, the most adequate variable for the explanation of distribution patterns of Spermatophyta and Arthropoda. We show that there are more variables representing either ecological or distance related factors that could explain most variance of the pattern. Therefore, the identified linkage between species number and pSIE could be driven by hidden underlying processes. WhitTAKer et al. (2007, 2008 ) suggest that a higher complexity of an island will enable more colonists to find suitable habitats to establish. This will further on intensify the adaptive radiation of already established species. With time, this will deepen the genetic gap between 

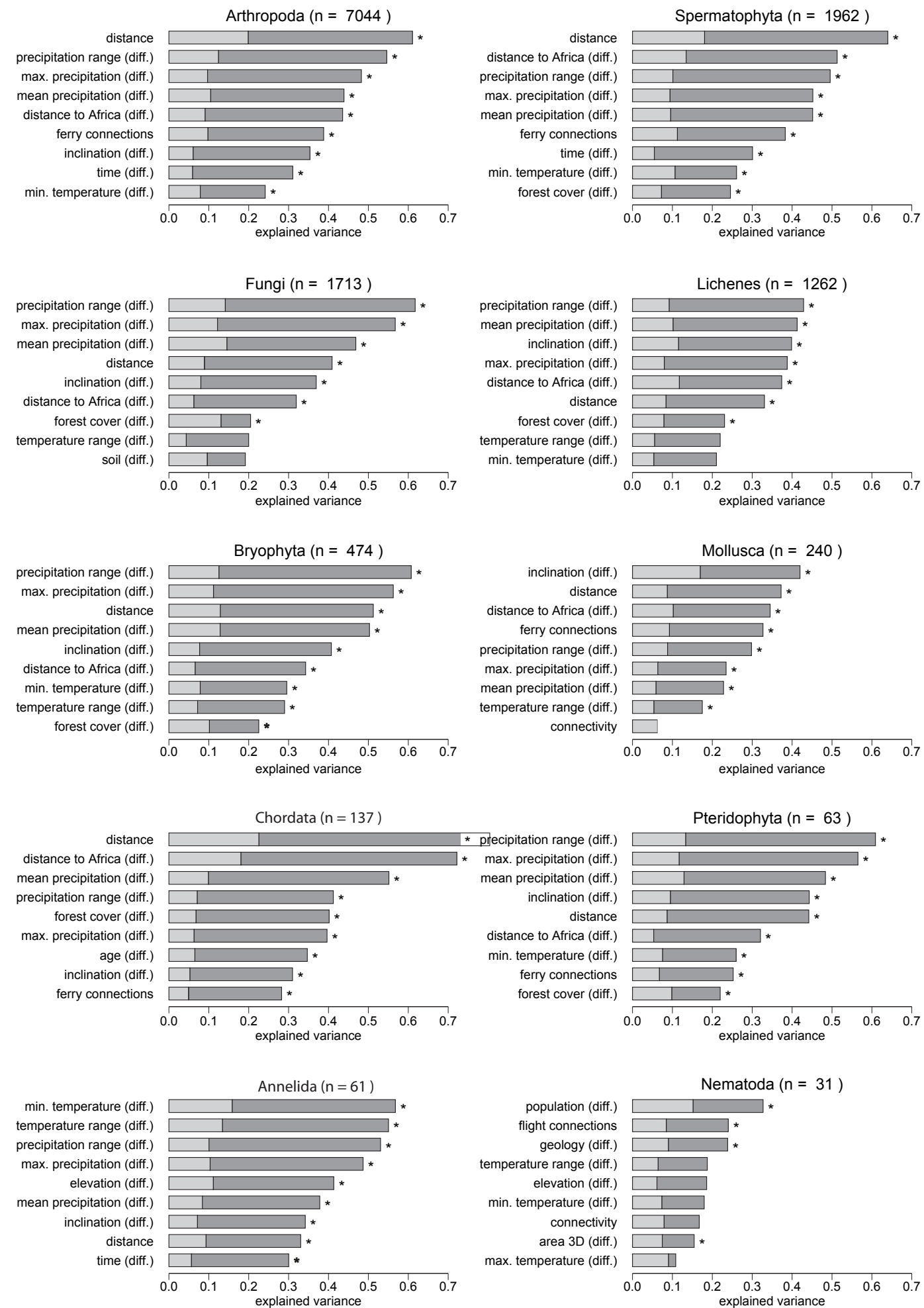

Fig. 4: Beta diversity was analysed using hierarchical partitioning. The grey parts of the bars illustrate the amount of variance that a variable can explain independently, black parts show the amount of variance a variable can explain together with the other variables. Note that the Euclidian distance of the variables listed in table 1 was used for the analyses of similarity. Significance $(p<0.05)$ is indicated by a star behind the bar. The sum of all single island endemic species of a group on the Canary Islands is indicated in brackets. 


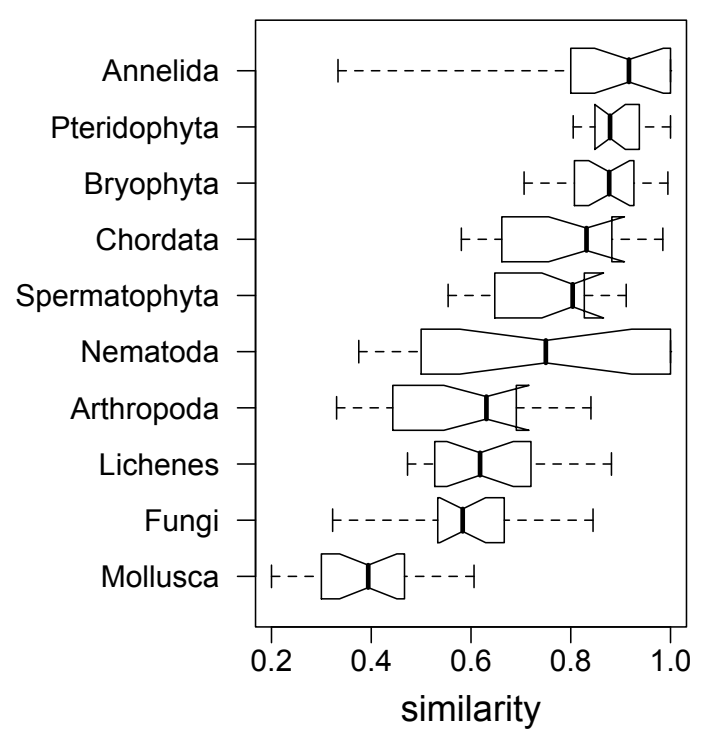

Fig. 5: Similarity values for pairs of islands differentiated for species groups. Dark lines in the box-and-whisker plots represent the median values, boxes indicate quartiles and whiskers data extremes.

populations on different islands. It is assumed that speciation is stimulated by the availability of more ecological niches. These are considered to be especially diverse on young and topographically heterogeneous islands. Heaney (2000) points to the fact that immigration and speciation exclude each other to a certain extent. Both are related to distance from a species source region.

These linkages between speciation, ecological complexity (WhitTAKer et al. 2007, 2008) and the distance to species source region (HEANEY 2000; LOMOLINo 2000a), together with the results presented here, suggest an alternative explanation for the correlation between species richness and pSIE. There might be an isolation gradient with altitude within an island. High elevation ecosystems on the mainland (possible source regions) are more probably to be found in the inland, far from to the coastline. Consequently, high elevation ecosystems on islands are farther away from potential species source regions on the mainland than this is the case for low elevation ecosystems. Species that have adapted to high elevation ecosystems have to cross a larger distance and a larger ecological gradient to reach a suitable habitat than low elevation species. The high elevation ecosystems are genetically more isolated (low immigration rate) and will thus have a higher rate of speciation. In the case of the Canary Islands, ecosystems with comparable altitude as El Teide (Tenerife) can again be found in the High Atlas Mountains. In future research, investigations on species distribution and speciation on oceanic islands should not only focus on island level, but rather also differentiate zonal ecosystems on these islands.

\subsection{Similarity in species composition (H2)}

On the Canary Islands, similarity in species composition is strongly influenced by geographic distance (falsifying hypothesis 2). The high explanatory power of the distance between the islands and the differences in the distance to mainland Africa for similarity values confirms the rule of "distance-decay" (NeKola and White 1999; BASELGA 2007). Contributing mechanisms are the decline in the exchange of organisms, an increasing dissimilarity in abiotic and biotic circumstances and distance itself (Nekola and White 1999).

Hints on the migratory and dispersal ability within species groups can be obtained by using the explanatory power of distance (Fig. 6) together with the median values of similarity in species composition (Fig. 5). Wind dispersal of diaspores between islands may explain the high values in similarity within plants. The slight increase in mean similarity from Spermatophyta over Bryophyta to Pteridophyta indicates increased colonisation success, probably due to the smaller size of spores and thus a larger importance of wind dispersal in the later groups. As nearly all other ways of dispersal are more constrained by distance than wind dispersal, the decrease in explanatory power by distance (Fig. 6) from Spermatophyta to Pteridophyta supports this hypothesis. However, Fungi, which can be dispersed via microscopic spores as well, were expected to have higher similarity values. One explanation may be the close dependence on a specific environment or host organism (e.g. Spermatophyta). Many fungi can only establish themselves if taxa of an other group of organisms are already there. Low median values in similarity for Mollusca represent the low dispersal ability of this group. A low explanatory power of the distance-decay relationship could indicate that immigration is more dependent on stochastic events (like birds transporting eggs from one island to the next) than on migration. High similarity values together with a strong distance-decay for Chordata might reflect that some species within the group (such as birds) have colonised all islands, while others (such as amphibians) have limited capacity to cross the ocean. 

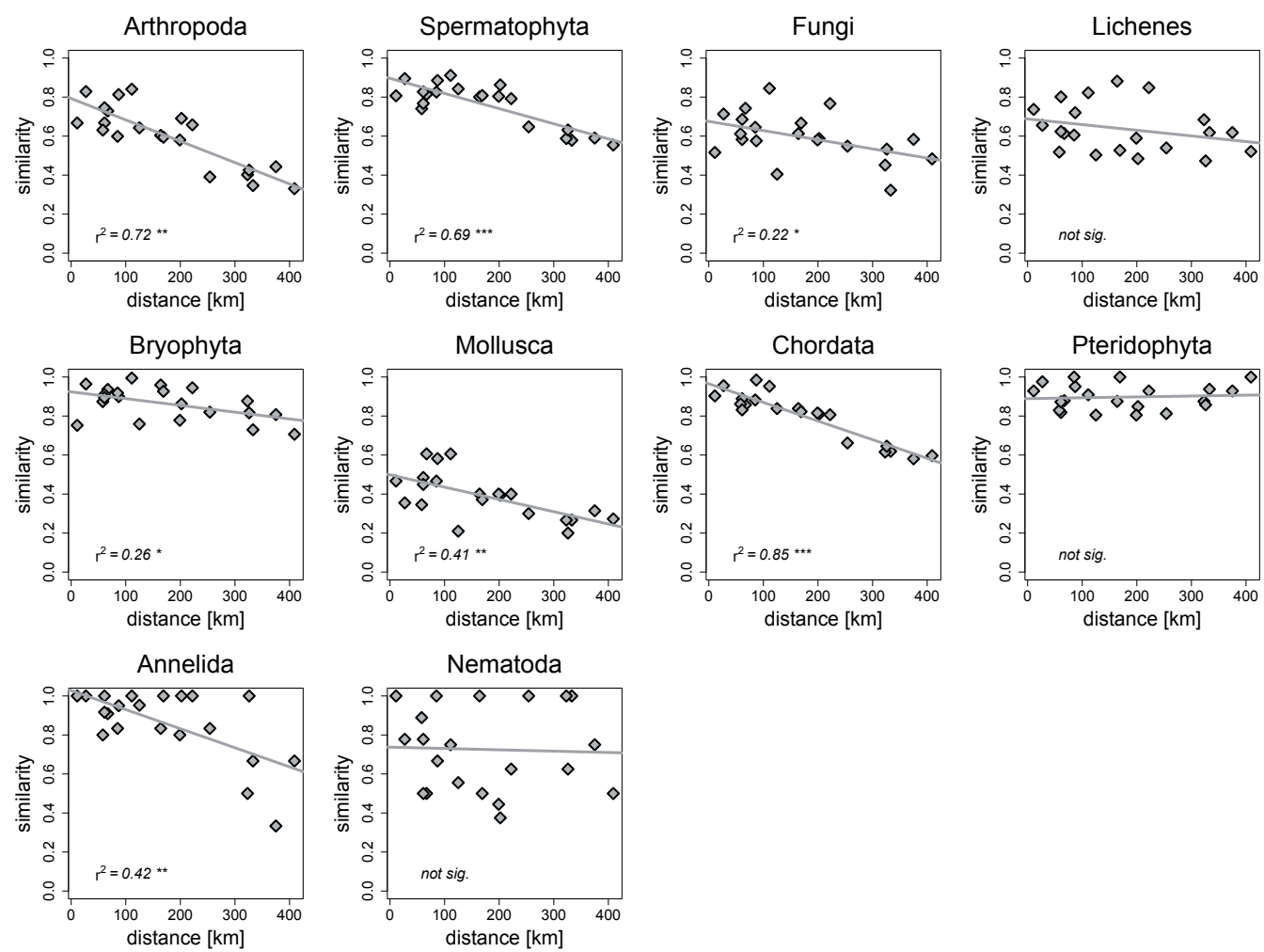

Fig. 6: Relationship between similarity of species composition and geographical distance between the islands. Each dot marks one of a total of 21 interinsular relationships.

\subsection{Changes in ecological settings}

Historic changes in the ecological settings of islands (e.g. pedogenesis, erosion, tectonic activity) and modifications of the distances between them (e.g. temporarily available stepping stones, sea level rise) contribute to the explanation of species distribution and speciation on archipelagos. The apparent problem is the difficulty, if not impossibility, to measure or capture historical conditions. As we can not ignore the importance of time and age, proxies have to be included in analyses. In this paper, island age has been corrected for volcanic events that have sterilised the whole surface of an island. 3.5 million years ago, the island of Gran Canaria was sterilised by the eruption of the Roque Nublo. Only two small hideaways remained after the catastrophe (FrANCISCO-ORTEGA et al. 1996).

Eustatic sea level fluctuations during the Pleistocene (more than $100 \mathrm{~m}$ ) alternately doubled and halved the area of the islands from $14,000 \mathrm{~km}^{2}$ during the glacial periodto $7,500 \mathrm{~km}^{2}$ during the interglacial (García-Talavera 1999). During the climax of the last glaciation, the relative elevation of the islands was about $130 \mathrm{~m}$ higher than the present elevation. Fuerteventura and Lanzarote were connected, forming the island of Mahan with a surface of $5,000 \mathrm{~km}^{2}$. The distance to the African mainland diminished from today's $100 \mathrm{~km}$ to roughly $60 \mathrm{~km}$. In addition, small sea mounds exceeded the sea level as islands and formed "stepping stones" between the Canary Islands, Madeira and the Iberian Peninsula (Whittaker and Fernández-Palacios 2007). This might have promoted species interchange between the islands.

The evolution of island biodiversity does not only reflect the continuous and long-term development of relief and environment. Single short-term events such as volcanic eruptions and large landslides have strong impacts. By eradicating a large percentage of a certain population, such events might contribute to a narrowing of the genetic pool (MoyA et al. 2004). A diminishing population can suffer from inbreeding depression. The genetic depletion can lead through a "bottle neck". After this an increasing population size cannot re-establish the previous genetic diversity and ecological range of the surviving species. Due to limitations in access and measurement, extreme events have been neglected in ecology for a long time. In face of climatic changes, there 
is increasing attention on disturbances and extremes (Jentsch and Beierkuhnlein 2008). We expect that this perspective will be even more important when evaluating the future development of island floras and faunas.

\section{Conclusions}

Our results support a strong contribution of ecological complexity to the pattern of species richness. In contrast to other cases (LOMOLINO 2000b; TJORve 2003; Triantis et al. 2003), on the Canary Islands elevation is shown to be a more suitable variable than island area to detect complexity and diversity.

Especially on islands with high elevations, distance from high elevation habitats to comparable sites on other islands or on the mainland might vary strongly. High altitude ecosystems on the continent, which are potential sources for species immigration on islands might be far away from the coast in the inland. In the case of the alpine communities of the Canary Islands, the nearest neighbours are found in the Atlas Mountains in Morocco. The distance an immigrating species has to overcome affects the driving processes of island biodiversity like immigration or speciation. However, distance and mechanisms are linked to the "ecological" distance between potential habitats and not to the mere geographic distance between islands and a continent. We therefore suggest to focus further research on the ecosystem scale, rather than the island scale. An appropriate approach is to work with elevation zones or with specific ecological settings.

\section{Acknowledgements}

We wish to thank Julian Zeidler and Reinhold Stahlmann for their support.

\section{References}

Anguita, F.; Márquez, A.; Castineiras, P. and Hernàn, F. (2002): Los volcanes de Canarias. Guía geológica e itinerarios. Alcorón (Madrid).

BaselgA, A. (2007): Disentagling distance decay of similarity from richness gradients: response to Soininen et al. 2007. In: Ecography 30, 838-841. doi:10.1111/ j.2007.0906-7590.05191.x

Beierkuhnlein, C. (1998): Biodiversität und Raum. In: Die Erde 128, 81-101.
- (2007): Biogeographie. Die räumliche Organisation des Lebens in einer sich verändernden Welt. Stuttgart.

Brown, J. H. and Kodric-Brown, A. (1977): Turnover rates in insular biogeography. Effects of immigration on extinction. In: Ecology 58, 445-449. doi:10.2307/1935620

Brown, J. H. and Lomolino, M. V. (2000): Concluding remarks: historical perspective and the future of island biogeography theory. In: Global Ecol. Biogeogr. 9, 87-92. doi:10.1046/j.1365-2699.2000.00186.x

Carroll, S. P.; Hendry, A. P.; Reznick, D. N. and Fox, C. W. (2007): Evolution on ecological time-scales. In: Funct. Ecol. 21, 387-393. doi:10.1111/j.13652435.2007.01289.x

Chevan, A. and Sutherland, M. (1991): Hierarchical partitioning. In: Am. Stat. 45, 90-96. doi:10.2307/2684366

Connor, E. F. and Mc Coy, E. D. (1979): Statistics and biology of the species-area relationship. In: Am. Nat. 113, 791-833. doi:10.1086/283438

CONSEJERÍA DE POLÍTICA TERRITORIAL Y MEDIO AMBIENTE GOBIERNO DE CANARIAS (2000): Plan Forestal de Canarias.

Dapporto, L. and Dennis, R. L. H. (2008): Species richness, rarity and endemicity on Italian offshore islands: complementary signals from island-focused and speciesfocused analyses. In: J. Biogeogr. 35, 664-674.

Del Arco. M. (2008): La flora y la vegetación canaria ante el cambio climático actual. In: Afonso-Carrillo, J. (ed.): Naturaleza amenazada por los cambios en el clima. Puerto de la Cruz, Tenerife, 105-140.

Del Arco, M.; Acebes, J. R. and Pérez-De-Paz, P. L. (1996): Bioclimatology and climatophilous vegetation of the Island of Hierro. In: Phytocoenologia 26, 445-479.

Del Arco, M.; Acebes, J. R.; Pérez-De-Paz , P. L. and Marrero, M. C. (1999): Bioclimatology and climatophilous vegetation of Hierro (part 2) and La Palma (Canary Islands). In: Phytocoenologia 29, 253-290.

Del Arco, M.; Salas, M.; Acebes, J. R.; Marrero, M. C.; Reyes-Betancort, J. A. and Pérez De Paz, P. L. (2002): Bioclimatology and climatophilous vegetation of Gran Canaria (Canary Islands). In: Ann. Bot. Fenn. 39, 15-41.

Del Arco, M.; Pérez De Paz, P. L.; Acebes, J. R.; GonzálezMancebo, J. M.; Reyes-Betancort, J. A.; Bermejo, J. A.; De Armas, S. and González-González, R. (2006): Bioclimatology and climatophilous vegetation of Tenerife (Canary Islands). In: Ann. Bot. Fenn. 43, 167-192.

Del Arco, M.; Rodríguez-Delgado, O.; Acebes, J. R.; García-Gallo, A.; Pérez De Paz, P. L.; GonzálezMancebo, J. M.; GonzÁlez-GonzÁlez, R. and Garzón, V. (2009): Bioclimatology and climatophilous vegetation of Gomera (Canary Islands). In: Ann. Bot. Fenn. 46, 161-191.

Duarte, M. C.; Rego, F.; Romeiras, M. M. and Moreira, I. (2008): Plant species richness in the Cape Verde islands 
- eco-geographical determinants. In: Biodivers. Conserv. 17, 453-466. doi:10.1007/s10531-007-9226-y

Emerson, B. C. and Kolm, N. (2005): Species diversity can drive speciation. In: Nature 434, 1015-1017. doi:10.1038/ nature 03450

Fernández-Palacios, J. M. and Andersson, C. (2000): Geographical determinants of the biological richness in the Macaronesian region. In: Acta Phytogeographica Suecica $85,41-50$.

Fernández-Palacios, J. M. and Whittaker, R. J. (2008): The Canaries: An important biogeographical meeting place. In: J. Biogeogr. 35, 379-387. doi:10.1111/j.13652699.2008.01890.x

Fernando-Pullé, D. (1976): Climatic characteristics of the Canary Islands. In: KunKel, E. (ed.): Biogeography and ecology in the Canary Islands. Monographiae Biologicae 30. The Hague.

Francisco-Ortega, J.; Jansen, R. K. and Santos-Guerra, A. (1996): Chloroplast DNA evidence of colonization, adaptive radiation, and hybridization in the evolution of the Macaronesian flora. In: Proc. Natl. Acad. Sci. USA 93, 4085-4090. doi:10.1073/pnas.93.9.4085

Fussmann, G. F.; Loreau, M. and Abrams, P. A. (2007): Eco-evolutionary dynamics of communities and ecosystems. In: Funct. Ecol. 21, 465-477. doi:10.1111/j.13652435.2007.01275.x

García-Talavera, F. (1999): La Macaronesia. Consideraciones geológicas, biogeográficas, y paleoecológicas. In: Fernández Palacio, J.; Bacallado, J. J. and Belmonte, J. A. (eds.): Ecología y cultura en Canarias. Santa Cruz de Tenerife, 39-64.

Goslee, S. C. and Urban, D. L. (2007): The ecodist package for dissimilarity-based analysis of ecological data. In: Journal of Statistical Software 22, 1-19.

Halas, D.; Zamparo, D. and Brooks, D. R. (2005): A historical biogeographical protocol for studying biotic diversification by taxon pulses. In: J. Biogeogr. 32, 249-260. doi:10.1111/j.1365-2699.2004.01147.x

Hamilton, T. H.; Rubinoff, I.; Bush, G. L. and Barth, R. H. (1963): Species abundance - natural regulation of insular variation. In: Science 142, 1575-1577.

Hannus, J. J. and von Numers, M. (2008): Vascular plant species richness in relation to habitat diversity and island area in the Finnish Archipelago. In: J. Biogeogr. 35, 1077-1086.

Heaney, L. R. (2000): Dynamic disequilibrium: a long-term, large-scale perspective on the equilibrium model of island biogeography. In: Global Ecol. Biogeogr. 9, 59-74. doi:10.1046/j.1365-2699.2000.00163.x

- (2007): Is a new paradigm emerging for oceanic island biogeography? In: J. Biogeogr. 34, 753-757. doi:10.1111/ j.1365-2699.2007.01692.x

Heikkinen, R. K.; Luoto, M.; Kuussaari, M. and Pöyry, J. (2005): New insights into butterfly-environment re- lationships using partitioning methods. In: Proceedings of the Royal Society 272, 2203-2210. doi:10.1098/ rspb.2005.3212

INSTITUTO GEOGRÁFICO NACIONAL (1994): Atlas Nacional de España. Madrid.

INSTITUTO NACIONAL DE ESTADISTICA (2005): Anuario Estadístico de España. Madrid.

Izquierdo, I.; Martín, J. L.; Zurita, C. and Arechavaleta, M. (2004): Lista de especies silvestres de Canarias. Hongos, plantas y animales terrestres. Consejería de Médio Ambiente y Ordenación Territorial, Gobierno de Canarias, La Laguna. Santa Cruz de Tenerife.

Jentsch, A. and Beierkuhnlein, C. (2008): Research frontiers in climate change: Effects of extreme meteorological events on ecosystems. In: CR Geoscience 340, 621628. doi:10.1016/j.crte.2008.07.002

JURASINSKI, G. (2007): simba: a collection of functions for similarity calculation of binary data. R-package.

Jurasinski, G.; Retzer, V. and Beierkuhnlein, C. (2009): Inventory, differentiation, and proportional diversity - a consistent terminology for quantifying biodiversity. In: Oecologia 159, 15-26. doi:10.1007/s00442-008-1190-z

Kinnison, M. T. and Hairston, N. G. (2007): Eco-evolutionary conservation biology: contemporary evolution and the dynamics of persistence. In: Funct. Ecol. 21, 444 454. doi:10.1111/j.1365-2435.2007.01278.x

Koleff, P.; Gaston, K. J. and Lennon, J. J. (2003): Measuring beta diversity for presence-absence data. In: J. Anim. Ecol. 72, 367-382. doi:10.1046/j.1365-2656.2003.00710.x

Kreft, H.; Jetz, W.; Mutke, J.; Kier, G. and Barthlott, W. (2008): Global diversity of island floras from a macroecological per- spective. In: Ecol. Lett. 11, 116-127.

Lomolino, M. V. (2000a): A call for a new paradigm of island biogeography. In: Global Ecol. Biogeogr. 9, 1-6. doi:10.1046/j.1365-2699.2000.00185.x

- (2000b): Ecology's most general, yet protean pattern: the species-area relationship. In: J. Biogeogr. 27, 17-26. doi:10.1046/j.1365-2699.2000.00377.x

MacArthur, R. H. and Wilson, E. O. (1967): The theory of island biogeography. Princeton.

Mac Nally, R. (2002): Multiple regression and inference in ecology and conservation biology: further comments on identifying important predictor variables. In: Biodiv. Cons. 11 (8), 1397-1401.

Marrero, A. and Francisco-Ortega, J. (2002): Evolución en islas: la metáfora espacio-tiempo-forma. In: FERNÁNDEZPalacios, J. M. and Martín Esquivel, J. L. (eds.): Naturaleza de las Islas Canarias. Ecología y conservación. Santa Cruz de Tenerife, 133-140.

McMaster, R. T. (2005): Factors influencing vascular plant diversity on 22 islands off the coast of eastern North America. In: J. Biogeogr. 32, 475-492. doi:10.1111/ j.1365-2699.2004.01200.x 
Morrison, L. W. (2002): Determinants of plant species richness on small Bahamian islands. In: J. Biogeogr. 29, 931-941. doi:10.1046/j.1365-2699.2002.00730.x

Moya, O.; Contreras-Diaz, H. G.; Oromi, P. and Juan, C. (2004): Genetic structure, phylogeography and demography of two ground-beetle species endemic to the Tenerife laurel forest (Canary Islands). In: Mol. Ecol. 13, 3153-3167. doi:10.1111/j.1365-294x.2004.02316.x

Nekola, J. C. and White, P. S. (1999): The distance decay of similarity in biogeography and ecology. In: J. Biogeogr. 26, 867-878. doi:10.1046/j.1365-2699.1999.00305.x

Panitsa, M.; Tzanoudakis, D.; Triantis, K. A. and SfENTHourakis, S. (2006): Patterns of species richness on very small islands: the plants of the Aegean archipelago. In: J. Biogeogr. 33, 1223-1234. doi:10.1111/j.13652699.2006.01481.x

Preston, F. W. (1960): Time and space and the variation of species. In: Ecology 41, 611-627. doi:10.2307/1931793

PRICE, J. P. (2004): Floristic biogeography of the Hawaiian Islands: influences of area, environment and paleogeography. In: J. Biogeogr. 31, 487-500.

Pulliam, H. R. (1988): Sources, sinks, and population regulation. In: Am. Nat. 132, 652-661. doi:10.1086/284880

R Development Core Team (2008): R: A language and environment for statistical computing. Vienna.

Reyes-Betancort, J. A.; Wildpret de la Torre, W.; LeónArencibia, M. C. (2001): The vegetation of Lanzarote (Canary Islands). In: Phytocoenologia 31, 185-247.

Ricklefs, R. E. and Bermingham, E. (2002): The concept of the taxon cycle in biogeography. In: Global Ecol. Biogeogr. 11, 353-361. doi:10.1046/j.1466-822x.2002.00300.x

Rodríguez Delgado, O.; García-Gallo, A. and MarreroGómez, M. V. (2005): El bioclima y la biogeografía. In: Rodríguez Delgado, O. (ed.): Patrimonio natural de la Isla de Fuerteventura. Cabildo de Fuerteventura. Gobierno de Canarias y Centro de la Cultura Popular Canaria. Arafo. Tenerife, 91-100.

Roos, M. C.; Kessler, P. J.; Gradstein, S. R. and BaAs, P. (2004): Species diversity and endemism of five major Malesian islands: diversity-area relationships. In: J. Biogeogr. 31, 1893-1908. doi:10.1111/j.13652699.2004.01154.x

Sanmartin, I.; van der Mark, P. and Ronquist, F. (2008): Inferring dispersal: a Bayesian approach to phylogeny-based island biogeography, with special reference to the Canary Islands. In: J. Biogeogr. 35, 428-449. doi:10.1111/j.1365-2699.2008.01885.x

Sснмттт, T. (1998): Phytodiversität mediterraner Inseln. In: Geographische Rundschau 12, 680-688.

Schoener, T. W.; Spiller, D. A. and Losos, J. B. (2001): Natural restoration of the species-area relation for a lizard after a hurricane. In: Science 294, 1525-1528. doi:10.1126/science.1064396
TJorve, E. (2003): Shapes and functions of species-area curves: A review of possible models. In: J. Biogeogr. 30, 827-835. doi:10.1046/j.1365-2699.2003.00877.x

Triantis, K. A.; Mylonas, M.; LiKa, K. and VardinoyanNIS, K. (2003): A model for the species-area-habitat relationship. In: J. Biogeogr. 30, 19-27. doi:10.1046/j.13652699.2003.00805.x

Walsh, C. and Mac NALLY, R. (2008): hier.part: hierarchical partitioning. R-package.

Watson, D. M. and Peterson, A. T. (1999): Determinants of diversity in a naturally fragmented landscape: humid montane forest avifaunas of Mesoamerica. In: Ecography 22, 582-589.

WhitTAKeR, R. J. (2000): Scale, succession and complexity in island biogeography: are we asking the right questions? In: Global Ecol. Biogeogr. 9, 75-85. doi:10.1046/j.13652699.2000.00200.x

Whittaker, R. J. and Fernández-Palacios, J. M. (2007): Island Biogeography. Ecology, evolution, and conservation. Oxford.

Whittaker, R. J.; Triantis, K. A. and Ladle, R. J. (2008): A general dynamic theory of oceanic island biogeography. In: J. Biogeogr. 35, 977-994. doi:10.1111/j.13652699.2008.01892.x

Whittaker, R. J.; Ladle, R. J.; Araujo, M. B.; FernándezPalacios, J. M.; Delgado, J. D. and Arevalo, J. R. (2007): The island immaturity - speciation pulse model of island evolution: an alternative to the "diversity begets diversity” model. In: Ecography 30, 321-327. doi:10.1111/j.0906-7590.2007.04761.x

Willerslev, E.; Hansen, A. J.; Nielsen, K. K. and ADSERSEN, H. (2002): Number of endemic and native plant species in the Galapagos Archipelago in relation to geographical parameters. In: Ecography 25, 109-119. doi:10.1034/j.1600-0587.2002.250113.x

Williams, C. B. (1964): Patterns in the balance of nature and related problems in quantitative ecology. London.

\section{Authors}

Manuel J. Steinbauer Prof. Dr. Carl Beierkuhnlein Department of Biogeography University of Bayreuth 95440 Bayreuth Manuel.Steinbauer@uni-bayreuth.de carl.beierkuhnlein@uni-bayreuth.de 